\title{
Бальна оцінка стану хворих на хронічний тонзиліт за клінічними показниками залежно від характеру динаміки імунологічних показників
}

\author{
M. I. HERASYMYUK \\ I. Horbachevsky Ternopil State Medical University
}

\section{THE SCORING OF PATIENTS WITH CHRONIC TONSILLITIS STATED ON CLINICAL INDICATORS DEPENDING ON THE FEATURES OF THE IMMUNOLOGICAL PARAMETERS DYNAMICS}

\begin{abstract}
У статті проведено зіставлення співвідношення гамма-інтерферон/інтерлейкін-4 з бальною кількісною характеристикою клінічних параметрів у хворих після різних методів лікування хронічного тонзиліту. Встановлено, що середня сума балів у хворих, яким було показане хірургічне лікування, помітно перевищувала суму балів у хворих, яким проводили консервативну терапію. Кількісну відмінність спостерігали також і в залежності від динаміки досліджуваних імунологічних показників - вихідна середня сума балів була вищою у хворих із наступним зниженням співвідношення гамма-інтерферон/інтерлейкін-4 у процесі лікування порівняно 3 хворими, в яких мало місце зростання даного співвідношення. Також відмічено, що кращі результати консервативного лікування за бальною оцінкою були у підгрупі хворих із підвищенням співвідношення гамма-інтерферон/інтерлейкін-4 у процесі лікування, як за окремими показниками, так і за середньою сумою балів у цілому.
\end{abstract}

The article compares the ratio of gamma-interferon / interleukin- 4 with point quantitative characteristic of clinical parameters in patients after the different treatment of chronic tonsillitis. It was established that the average total score in patients who were indicated to surgical treatment significantly exceeded the amount of points than in patients who underwent conservative therapy. There was also the quantitative difference depending on the dynamics of the studied immunological parameters output average total score was higher in patients with subsequent reduction of ratio of gamma-interferon / interleukin- 4 during treatment comparing it with the patients who had an increase of this ratio. Also it was observed, that the best results of conservative treatment, according to the scoring scale, were in the subgroup of patients with an increase of the ratio of gammainterferon / interleukin- 4 during treatment, as in the individual indicators, and in the general average amount of points.

Постановка проблеми і аналіз останніх досліджень та публікацій. На сьогодні методи інтегральної оцінки стану хворих як за клінічними, так і за лабораторними критеріями, включаючи імунологічні, набувають усе більшого застосування. За основу при цьому беруть виражені в балах окремі клінічні й лабораторні параметри [1, 2].

Разом із тим, останнім часом значну увагу приділяють вивченню цитокінового профілю при алергічних захворюваннях, зокрема дисбалансу гамма-інтерферону (IFN-ү) й інтерлейкіну-4 (IL-4) лімфоцитів [3, 4]. IL-4 в комплексі з IFN- $ү \in$ ключовим фактором, що визначає тип імунітету [5]. Вважають, що більш інформативним показником $€$ динаміка їх співвідношення на відміну від простої констатації абсолютних рівнів. При інфекційно-алергічних захворюваннях відмічають зниження співвідношення концентрацій IFN-ץ/IL-4 як важливих складових процесу запалення, що характерно для реакцій гіперергічного типу [6].

Враховуючи те, що хронічний тонзиліт (XT) - це хронічне запалення піднебінних мигдаликів, що супроводжується пригніченням неспецифічних факторів природної резистентності організму, порушенням як гуморальної, так і клітинної ланок імунітету [7-9], ми зробили спробу порівняти характер динаміки співвідношення IFN- $/ / \mathrm{IL}-4$ із бальною кількісною характеристикою клінічних параметрів у хворих після різних методів лікування хронічного тонзиліту з метою покращення діагностики і контролю за ефективністю лікування хронічного тонзиліту.

Мета роботи: встановити залежність між характером співвідношення IFN-ү/IL-4 та бальною кількісною характеристикою клінічних параметрів у хворих після різних методів лікування хронічного тонзиліту. 
Матеріали і методи. Обстежено 36 хворих на XT, з яких у 20 випадках проводили консервативне лікування і в 16 - хірургічне. Контрольну групу склали 15 практично здорових осіб без ознак ЛОР-патології. Кожну з обстежених груп пролікованих пацієнтів було поділено на 2 підгрупи: зі зниженням співвідношення IFN- $\gamma / \mathrm{IL}-4$ у процесі лікування і з його зростанням. Пацієнтам, яким здійснювали хірургічне лікування, бальну клінічну оцінку проводили лише перед операцією, і їx дані використовували для порівняння.

При бальній оцінці стану хворих на хронічний тонзиліт та ефективності його лікування ми користувалися запропонованими Д. І. Заболотним і співавт. [1] клінічними показниками:

- ступінь гіперемії дужок (0 балів - відсутність гіперемії; 1 бал - незначна гіперемія дужок; 2 бали - виражена гіперемія дужок і слизової оболонки мигдаликів; 3 бали - виражена гіперемія дужок, слизової оболонки мигдаликів, бокових і задніх стінок глотки);

- наявність казеозно-гнійного детриту в лакунах (0 балів - відсутність вмісту в лакунах; 1 бал - тільки поодинокі казеозні “пробки”; 2 бали - помірне виділення з лакун казеозу і гною без натискування на тканину; 3 бали - гнійний вміст у лакунах);

- розміри мигдаликів (0 балів - у межах лінії дужок, нормальні; 1 бал - виходять за межі дужок незначно; 2 бали - різні розміри правого і лівого мигдаликів, що виходять за межі дужок; 3 бали виражена атрофія мигдаликів);

- стан підщелепних лімфовузлів (0 балів - у межах норми; 1 бал - незначно збільшені лімфовузли; 2 бали - періодично збільшені й болючі лімфовузли; 3 бали - постійно збільшені лімфовузли, періодична болючість при пальпації);

- кількість загострень на рік (0 балів - без загострень; 1 бал - загострення 1 раз на рік без ГРВ3; 2 бали - загострення 2 рази на рік; 3 бали - загострення більше 3 разів на рік);

- наявність супутніх захворювань (0 балів відсутність метатонзилярної патології; 1 бал - наявність хронічних захворювань ШКТ, щитоподібної залози; 2 бали - наявність хронічних захворювань нирок, суглобів з від'ємними ревмопробами; 3 бали - загроза щодо ревматизму, позитивні ревмопроби; 4 бали - наявність захворювань серця, суглобів, сполучної тканини з позитивними ревмопробами);

- термометрія тіла при загостренні хронічного тонзиліту (0 балів - нормальна температура; 1 бал - субфебрильна; 2 бали - близько $38^{\circ} \mathrm{C} ; 3$ бали - понад $\left.38^{\circ} \mathrm{C}\right)$.
Рівень цитокінів (IFN-ү та IL-4) лімфоцитів визначали на імуноферментному аналізаторі “STAT FAX 303/PLUS”.

Результати досліджень та їх обговорення. Зіставлення отриманих даних дозволило встановити, що у хворих на ХТ середня сума балів за клінічними показниками до початку лікування була значно вищою, ніж у контрольній групі обстежених (табл. 1). Причому у хворих, яким було показане хірургічне лікування, таке перевищення сягало 9,5-10 разів, а у хворих, яким проводили консервативне лікування, воно було 7-8-кратним. Тобто середня сума балів у хворих, яким було показане хірургічне лікування, помітно перевищувала суму балів у хворих, яким проводили консервативну терапію. Кількісну відмінність спостерігали також і в залежності від динаміки досліджуваних імунологічних показників - вихідна середня сума балів була вищою у хворих із наступним зниженням співвідношення IFN- $/$ /L-4 у процесі лікування порівняно з хворими, в яких мало місце зростання даного співвідношення.

Проведення консервативного лікування в обох підгрупах цієї групи хворих давало позитивний ефект, що підтверджувалося зменшенням у них середньої суми балів, встановленої за клінічними показниками. Особливо помітним було зниження кількості загострень і температури, досить інтенсивно знижувалися показники гіперемії, наявності казеозного детриту, а також розміри лімфатичних вузлів, при цьому менш інтенсивно зменшувались розміри мигдаликів.

Разом із тим, кращі результати консервативного лікування за бальною оцінкою було відмічено у підгрупі хворих із підвищенням співвідношення IFN- $\gamma / \mathrm{IL}-4$ у процесі лікування, як за окремими показниками, так і за середньою сумою балів у цілому (табл. 2). У хворих із підвищенням співвідношення IFN- $/$ /L-4 середня сума балів у процесі лікування знижувалася на 54,9 \%, тоді як у хворих з його зниженням така різниця складала лише 45,7 \%.

При цьому близький за ефективністю результат щодо зниження кількості казеозного детриту в обох підгрупах може бути зумовлений його регулярним вимиванням у процесі лікування, а майже однакова інтенсивність зменшення розмірів мигдаликів може бути наслідком зміни їх морфологічного стану ще до початку лікування.

У цілому, підсумовуючи результати проведеного дослідження, можна сказати, що при консервативному лікуванні хронічного тонзиліту підвищення співвідношення IFN- $/ / \mathrm{IL}-4$ є прогностично більш сприятливою ознакою, ніж його зниження. 
Таблиця 1. Кількісна характеристика стану хворих на хронічний тонзиліт за клінічними показниками залежно від характеру динаміки імунологічних показників при різних методах лікування

\begin{tabular}{|c|c|c|c|c|c|c|c|c|}
\hline \multirow[b]{2}{*}{ Метод лікування } & \multicolumn{8}{|c|}{ Клінічний показник } \\
\hline & $\begin{array}{l}\text { гіпере- } \\
\text { мія } \\
\text { дужок }\end{array}$ & $\begin{array}{l}\text { казеоз- } \\
\text { ний } \\
\text { детрит }\end{array}$ & $\begin{array}{c}\text { розміри } \\
\text { мигда- } \\
\text { ликів }\end{array}$ & $\begin{array}{c}\text { лімфо- } \\
\text { вузли }\end{array}$ & $\begin{array}{c}\text { загост- } \\
\text { рення }\end{array}$ & $\begin{array}{c}\text { супутні } \\
\text { захворю- } \\
\text { вання }\end{array}$ & $\begin{array}{l}\text { темпе- } \\
\text { ратура }\end{array}$ & сумарно \\
\hline Контроль & 0,6 & 0,47 & 0,33 & 0,2 & 0 & 0 & 0 & $0,23 \pm 0,15$ \\
\hline $\begin{array}{l}\text { До операційного ліку- } \\
\text { вання з підвищенням } \\
\text { співвідношення IFN-ү/ } \\
\text { IL-4 у процесі лікування }\end{array}$ & 2,33 & 2,5 & 1,17 & 2,33 & 2,83 & 2,5 & 1,67 & $2,19 \pm 0,34$ \\
\hline $\begin{array}{l}\text { До операційного } \\
\text { лікування зі зниженням } \\
\text { співвідношення IFN-ү/ } \\
\text { IL-4 у процесі лікування }\end{array}$ & 2,6 & 2,7 & 1,2 & 2,6 & 2,8 & 2,5 & 1,9 & $2,33 \pm 0,34$ \\
\hline $\begin{array}{l}\text { До консервативного } \\
\text { лікування } з \\
\text { підвищенням } \\
\text { співвідношення IFN-ү/ } \\
\text { IL-4 у процесі лікування }\end{array}$ & 2,21 & 1,93 & 1,5 & 2,07 & 1,28 & 0,91 & 1,57 & $1,64 \pm 0,28$ \\
\hline $\begin{array}{l}\text { Після консервативного } \\
\text { лікування з } \\
\text { підвищенням } \\
\text { співвідношення IFN-ү/ } \\
\text { IL-4 у процесі лікування }\end{array}$ & 1,28 & 1,07 & 1,21 & 1 & 0,14 & 0,28 & 0,21 & $0,74 \pm 0,35$ \\
\hline $\begin{array}{l}\text { До консервативного } \\
\text { лікування зі зниженням } \\
\text { співвідношення IFN-ү/ } \\
\text { IL-4 у процесі лікування }\end{array}$ & 2,5 & 2,33 & 1,67 & 2,17 & 1,5 & 1,17 & 1,67 & $1,86 \pm 0,31$ \\
\hline $\begin{array}{l}\text { Після консервативного } \\
\text { лікування зі зниженням } \\
\text { співвідношення IFN-ү/ } \\
\text { IL-4 у процесі лікування }\end{array}$ & 1,67 & 1,17 & 1,33 & 1,33 & 0,61 & 0,61 & 0,33 & $1,01 \pm 0,32$ \\
\hline
\end{tabular}

Таблиця 2. Порівняльна характеристика інтенсивності зниження клінічних показників (\%) у хворих на хронічний тонзиліт із підвищенням і зниженням співвідношення IFN-y/IL-4 у процесі лікування

\begin{tabular}{|c|c|c|c|c|c|c|c|c|}
\hline \multirow[b]{2}{*}{ Метод лікування } & \multicolumn{8}{|c|}{ ІІнтенсивність зниження клінічних показників (\%) } \\
\hline & $\begin{array}{l}\text { гіпере- } \\
\text { мія } \\
\text { дужок }\end{array}$ & $\begin{array}{l}\text { казеоз- } \\
\text { ний } \\
\text { детрит }\end{array}$ & $\begin{array}{c}\text { розміри } \\
\text { мигда- } \\
\text { ликів }\end{array}$ & $\begin{array}{c}\text { лімфо- } \\
\text { вузли }\end{array}$ & $\begin{array}{c}\text { загост- } \\
\text { рення }\end{array}$ & $\begin{array}{c}\text { супутні } \\
\text { захворю- } \\
\text { вання }\end{array}$ & $\begin{array}{l}\text { темпе- } \\
\text { ратура }\end{array}$ & сумарно \\
\hline $\begin{array}{l}\text { Після консервативного } \\
\text { лікування з } \\
\text { підвищенням } \\
\text { співвідношення IFN-ү/ } \\
\text { IL-4 у процесі лікування }\end{array}$ & 42,1 & 44,6 & 19,4 & 51,7 & 89,1 & 69,3 & 86,7 & 54,9 \\
\hline $\begin{array}{l}\text { Після консервативного } \\
\text { лікування зі зниженням } \\
\text { співвідношення IFN-ү/ } \\
\text { IL-4 у процесі лікування }\end{array}$ & 33,2 & 49,8 & 20,4 & 38,8 & 59,4 & 47,9 & 80,3 & 45,7 \\
\hline
\end{tabular}

Висновок. Динаміка співвідношення IFN- $/$ IL-4 може бути одним із критеріїв для оцінки ефективності консервативної терапії, а також прогнозування подальшої тактики лікування у хворих на хронічний тонзиліт.

\section{СПИСОК ЛІТЕРАТУРИ}

1. Заболотный Д. И. Балльная оценка клинико-иммунологического состояния больных хроническим тонзиллитом различного возраста / Д. И. Заболотный, О. Ф. Мельников,
А. Ю. Бредун // Журнал вушних, носових і горлових хвороб. - 2012. - № 3. - С. 15-20.

2. Трахтенберг И. М. Очерки физиологии и гигиены труда 


\section{З ДОСВІДУ РОБОТИ}

пожилого человека / И. М. Трахтенберг, А. А. Поляков. - К. : Изд. дом “Авиценна”, 2007. - 271 с.

3. Провоспалительные и противовоспалительные цитокины у недоношенных новорожденных с ОРДС / С. А. Перепелица, А. М. Голубев, В. В. Мороз [и др.] // Общая реаниматология. - 2009. - Т. V, № 6. - С. 21-30.

4. Цитокиновый спектр сыворотки крови у больных с акустической невриномой до и после лечения различными методами / О. Ф. Мельников, А. Ю. Минина, О. Н. Борисенко, М. Д. Тимченко // Журнал вушних, носових і горлових хвороб. - 2013. - № 2. - С. 36-38.

5. Кетлинский С. А. Роль Т-хелперов типов 1 и 2 в регуляции клеточного и гуморального иммунитета / С. А. Кетлинский // Иммунология. - 2002. - Т. 23, № 2. - С. 77-79.

6. Антонович Ж. В. Количественные критерии для оценки уровня контроля над бронхиальной астмой / Ж. В. Антонович // Военная медицина. - 2010. - № 1. - С. 52-55.

7. Красницкая А. С. Иммунологические аспекты хронического тонзиллита, асоциированного с вирус ЭпштейнБарра-инфекцией / А. С. Красницкая, Н. А. Боровская // Фундаментальные исследования. - 2012. - № 4. - С. 299305.

8. Тишко Ф. О. Клініко-морфологічне обгрунтування тонзилектомії та абсцестонзилектомії / Ф. О. Тишко, С. Г. Гичка, О. І. Вільчинський // Журнал вушних, носових і горлових хвороб. - 2013. - № 3-с. - С. 286-287.

9. Цимар А. В. Клінічна оцінка застосування імуномоделюючої терапії у хворих на хронічний тонзиліт / А. В. Цимар, О. І. Тинітовська // ХІІ з'їзд оториноларингологів України, 18-20 трав. 2015 р. - Львів, 2015. - С. 153-154.

Отримано 08.11.16 